challenge that "Anyone who disagrees with my forecast must try to get beyond a vague optimism. . . . In particular he must find a really solid reason which shows how the threat of over-population will be avoided ... or else he will find that his imagination has gone so far out of the realms of reality that it contradicts the physical or the biological laws of nature".

I have tried to show that there may be, if not really solid reasons, at least plausible arguments not inconsistent with the biological laws of Nature, on the basis of which we may question the fundamental Malthusian assumption that human fecundity has some constant and rather high mean value which could only be altered by artificial means. It is at least conceivably possible that prosperity may provide its own solution to the problem by being the cause of a natural lowering of the rate of increase of the population. Whether my argurnents have carried conviction, or whether we continue to believe in the essential correctness of Malthus's analysis, our actions at least will remain the same. No one seriously believes that we can or should deliberately limit increases in world food supplies, nor that we should withhold medical discoveries from over-populated regions, however much many may fear that the benefits they bring will in the end prove illusory. Nor does anyone doubt that these benefits will be the cause of an immediate and, in some parts of the world, at least, an undesirable increase in the present population, which should be restricted by all legitimate means, however much opinions may differ as to what means are legitimate. All I am suggesting is that it is just possible that what we are in any event bound to do may, if we do it in $\operatorname{time} \theta$ not lead our descendants inevitably to disaster.

\title{
EFFECTS ON AGRICULTURE OF CHANGES IN THE BALANCE OF NATURE
}

$\mathrm{T}$ HE morning session on August 31 of Section M (Agriculture) of the British Association during the Sheffield meeting was devoted to effects on agriculture of changes in the balance of Nature. Mr. E. M. Nicholson, director-general of the Nature Conservancy, opened the session with a paper on "Ecological Research and Farming". He emphasized the common interest of the farmer, forester and nature conservationist in an adequate and welldirected programme of fundamental research into the basic processes of Nature, including soil building, the balance of supply and demand for water, erosion, and the natural control of animal populations. Successful management of Nature, whether for foodgrowing, timber-growing or conservation, is dependent on a greatly improved knowledge of such processes, which may prove the key to an increase in the rate of formation of natural 'capital' and thus raise the potential 'income' in the form of renewable resources, including vegetation and water. The Nature Conservancy's researches on woodland soils, for example, include studies of the role of different tree species as soil improvers and soil impoverishers, and comparisons of productivity under different species of hardwood trees and conifers compared with weight increases shown by sheep on identical plots scattered within the same experimental area. Other factors being measured include the amount of water used by plantations of trees which would otherwise be available for stream-flow and for water-supply undertakings. It is possible to measure the potential yield of water supply under alternative land uses and to analyse the parts played by, for example, evaporation and transpiration. The Nature Conservancy is now recording potential evapo-transpiration daily in both the east and the north-west Scottish Highlands and in Wales and the Pennines, with results differing considerably from those which had been theoretically predicted.

The maintenance and enhancement of natural 'capital' involve studies now in progress at Moor House Field Station on the management of peat moors and the part played by different types of land management and land use in causing or preventing erosion, which is occurring at a formidable rate, for example, in the Trough of Bowland. Tree stumps and cattle horns of prehistoric age are found even above the $2,000 \mathrm{ft}$. contour, far above the level at which either exists to-day, and there is little doubt that trees of some sort, if only rowans, alders and willows, could under suitable land management cover some of those areas again, interspersed with improved herbage. In some areas fertility might be raised by making good the chance absence of some soilimproving animal or plant, such as the small hardy strain of wild white clover adapted to high altitudes and heavy rainfalls which has recently been found in North Wales (ef. Nature, 176, 596 ; 1955).

In discussing the balance of Nature, Mr. Nicholson emphasized that it must be remembered that every natural event, whether or not caused by human interference, opens certain doors and closes others. Civilization, unfortunately, closes many doors permanenily by excessive inroads into dwindling residues of so-called waste lands which are the last remaining reservoirs of irreplaceable stocks of genes evolved over millions of years.

Mr. Nicholson criticized popular attitudes towards pest control and quoted results obtained during nearly thirty years showing that the population of the heron in England and Wales has without control measures been effectively held at between 4,000 and 4,700 breeding pairs by ecological limitations. On the other hand, the wood pigeon has been greatly favoured by the systematic killing of its predators, such as sparrowhawks, and by the additional cover provided for breeding in young plantations. Control measures would be extremely difficult in face of these ecological stimuli to expansion. Rabbits became a major pest directly owing to human encouragement, and future rabbit populations will depend mainly on whether we have the will to prevent them, as we can, from returning to former levels.

Nature and its study should be regarded as intimately concerning farmers and foresters, who should aim at understanding and working with Nature, rather than using too many mechanical and chemical short cuts. A moralizing attitude towards our fellow predators on the Earth is out of place, and more understanding should be shown of their important role. As the fine and all-embracing tradition of the great estates has lost its impetus, ecological research may become the basis of a new and equally fruitful outlook, reconciling needs for growing food and 
timber with the need to keep the country worth living in for all its creatures, including people.

Dr. I. Thomas, of the Ministry of Agriculture, Fisheries and Food, read a paper on the "Natural and Artificial Control of Vertebrate Pests of Agriculture". He referred to that widely used and dangerous expletive, 'vermin', and gave illustrations of the different categories in which predators must be placed according to whether the point of view is that of growing crops or preserving game. In dis. cussing the economic balance-sheet in Britain for the rabbit, he pointed out that while on the credit side rabbits have been estimated to yield products valued at $£ 15$ million annually, probably less than $£ 2$ million of this accrued to agriculture. On the debit side, estimated losses before myxomatosis ranged between $£ 45$ and $\mathfrak{f 6 0}$ million. Rabbit trapping had, especially in its early stages, killed large numbers of predators, including foxes, weasels, stoats and polecats, and some of these predators had been exterminated over certain areas, thus helping greatly to enable the rabbit population to get out of hand. Dr. Thomas gave figures showing that the disappearance of rabbits has not greatly affected either the numbers of foxes or their depredations on livestock.

Dr. Thomas said that where rabbits have been seriously reduced, wood pigeons are now perhaps the farmer's greatest vertebrate pest; yet man has created the conditions for pigeons to multiply. Increased acreages under brassica and pea cultivation have provided much additional attractive food, and it is difficult to protect these crops by methods which are free of risk of killing game such as pheasants. More than $2 \frac{1}{2}$ million wood pigeons were reported to have been shot in England and Wales in 1955 and 445,000 during the first quarter of 1956. In this quarter alone, the cartridges probably cost more than $£ 28,000$, and 50 per cent of this sum could be claimed in subsidy. Adding this to the agricultural damage (which is very heavy also on, for example, elover leys), wood pigeons are costing Great Britain large sums of money. Dr. Thomas pointed out that while rabbits can be controlled estate by estate, relief from wood pigeon damage requires control over the whole national pigeon population. There is, therefore, little ground for optimism on this problem.

In a paper on "Insect Pest Balance in Agriculture", Mr. A. H. Strickland, of the Plant Pathology Laboratory, Harpenden, Herts, referred to the difficulty of relating the mathematical theories put forward by Lotka, Volterra, Nicholson and Bailey regarding growth and decline of populations to biological data so far available. Proponents of the probabilistic school have suggested, for example, that plagues of a grasshopper Austroicetes cruciata would occur in certain favourable areas five or six times in a century, but there is no way yet of forecasting when a plague will occur. Little work has been done so far on natural populations in the field; but ten years ago the National Agricultural Advisory Service Conference of Entomologists started routine assessments of the annual peak population densities of about a dozen insect pests throughout England and Wales, and six years ago the scheme was widened somewhat in scope to include detailed work on population density in relation to economic damage. In 1946 an 'Extensive Survey' was begun of the cabbage aphid (Brevicoryne brassicae), based on an annual random sample of about a hundred unsprayed brussels sprout crops throughout Britain. From 1951 this was supplemented by field-plot experiments set up in commercial sprout fields in the main sprout-growing areas. The results to date show that damage by cabbage aphid to brussels sprouts alone is equivalent to $4,500-10,500$ acres a year, the average annual financial loss over the past ten years having been $£ 868,000$. Organo-phosphorous insecticide spraying, wherever economically justifiable, might have reduced this loss to about $£ 500,000$.

Ten years extensive survey has also been made of frit fly (Oscinella frit) infestation at harvest, and yield samples are being threshed at Rothamsted for the fifth season. Four experimental treatments have been tested. It appears that, on average in England and Wales, about 3 per cent of oat shoots are killed and about 5 per cent of oat grains are damaged by frost and second-generation larvæ respectively. This implies losses of $1 \cdot 8 \mathrm{cwt}$. per acre from shoot destruction and a further 3.5 cwt. per acre from grain damage. The frit flies are thus estimated to cost farmers in England and Wales some $£ 10$ million annually. Complete frit control could raise the average national oat yield from $18 \cdot 6$ to about 24 cwt. per acre.

Mr. Strickland emphasized that toxic chemicals are at best palliatives, and are unlikely to provide a permanent solution, which must be sought by changes in agricultural practice leading to conditions less favourable to a high rate of increase of the pest. $\mathrm{He}$ cited A. Milne's recent findings that the sheep tick (Ixodes ricinus) can be largely controlled by minor alterations in flock management reinforced by re-seeding of old moorland pastures, while the wheat bulb fly Hylemyia coarctata can also be affected by suitable rotational and cultural practices. Aphid infestations can be shown to be less severe on fields of five acres than on larger fields, and even drilling a few rows of a cereal at appropriate intervals can mitigate losses from aphids. Finally, Mr. Strickland referred to the recent eradication of the screw worm Callitroga hominivorax in Curacao by releasing 16 million pupæ sterilized with gamma rays so that the normal females with whom the sterilized males mated laid sterile eggs. He concluded that further advances in understanding the environmental factors which prevent insect pests from increasing to an unlimited extent depend largely on development of co-operative field-work on the lines recently adopted in Britain.

There was an interesting discussion on a wide variety of topies arising from the papers. Mr. Cook (Ceylon) described difficulties met in coconut research from an even larger pest, the elephant, breaking into seed gardens despite deep trenches, powerful electric fences and other obstructions which were easily circumvented. Noise and the smell of burning rubber tyres appeared the best deterrents. Cattle had been induced to cease eating experimental plants by adding a special food supplement to their normal grazing diet.

Several speakers expressed concern over the problems of reconciling current game preservation patterns with agricultural needs, and asked that the subject should be explored.

This experiment in bridging gaps between the ecological and agricultural approaches was regarded as well worth while, and the convergence of the views expressed from such different angles by the three speakers was remarkable, especially as regards the need for studying pest and other problems from an environmental or ecological point of view, rather than seeking chemical or mechanical magic wands. 